\title{
Heats of Formation of Lithium Perchlorate, Ammonium Perchlorate, and Sodium Perchlorate
}

\author{
Alexis A. Gilliland and Walter H. Johnson
}

(October 5, 1960) \begin{abstract}
and $\mathrm{NaClO}_{4}(\mathrm{c})$ have been made. The results have been combined with the heats of formation of $\mathrm{KClO}_{4}(\mathrm{c}), \mathrm{KCl}(\mathrm{c}), \mathrm{LiCl}(\mathrm{c}), \mathrm{NH}_{4} \mathrm{Cl}(\mathrm{c})$, and $\mathrm{NaCl}(\mathrm{c})$, to obtain the following heats of formation:

$\begin{aligned} \mathrm{LiClO}_{4}(\mathrm{c}), \quad \Delta \mathrm{Hf}^{\circ}\left(25^{\circ} \mathrm{C}\right) & =-380.27 \pm 1.21 \mathrm{kj} / \mathrm{mole} \\ & =-90.89 \pm 0.29 \mathrm{kcal} / \mathrm{mole}, \\ & =-295.98 \pm 1.35 \mathrm{kj} / \mathrm{mole} \\ \mathrm{NH}_{4} \mathrm{ClO}_{4}(\mathrm{c}), \quad & =-70.74 \pm 0.32 \mathrm{kcal} / \mathrm{mole}, \\ \mathrm{NaClO}_{4}(\mathrm{c}), \quad & =-382.75 \pm 0.93 \mathrm{kj} / \mathrm{mole} \\ & =-91.48 \pm 0.22 \mathrm{kcal} / \mathrm{mole} .\end{aligned}$
\end{abstract}

Calorimetric measurements of the heats of solution of $\mathrm{LiClO}_{4}(\mathrm{c}), \mathrm{NH}_{4} \mathrm{ClO}_{4}(\mathrm{c})$,

A brief summary of other recent data has been included.

\section{Introduction}

This investigation, a continuation of the work described in the preceding paper, was undertaken to obtain a reliable value for the heat of formation of sodium perchlorate and to provide a uniform basis for intercomparing the heats of formation of lithium, ammonium, sodium, and potassium perchlorates. Because of uncertainties in the data used for obtaining the heat of formation of perchloric acid, a method was chosen in which the heats of formation of the perchlorates were obtained in terms of the literature data on potassium perchlorate and on the corresponding chlorides.

\section{Materials}

The $\mathrm{LiCl}, \mathrm{NaCl}, \mathrm{KCl}$, and $\mathrm{NH}_{4} \mathrm{Cl}$ were reagentgrade materials, dried at $130{ }^{\circ} \mathrm{C}$, and stored in a desiccator over anhydrous magnesium perchlorate.

The $\mathrm{KClO}_{4}$ was reagent-grade material, recrystallized twice from water, and dried at $110{ }^{\circ} \mathrm{C}$.

The $\mathrm{LiClO}_{4}$ was obtained from HEF, Inc., a corporation owned and operated jointly by the Hooker Chemical Company and the Foote Mineral Company. The following analysis in percent was furnished with the material: $\mathrm{LiClO}_{4}, 99.7 ; \mathrm{H}_{2} \mathrm{O}, 0.1$; $\mathrm{NaCl}, 0.1 ; \mathrm{NaClO}_{3}, 0.005 ; \mathrm{R}_{2} \mathrm{O}_{3}, 0.01$. However, the material had apparently been subjected to brief exposures to moisture, as it was found by the Karl Fischer method to contain approximately 1.84 percent of water. Heating the material overnight at $160{ }^{\circ} \mathrm{C}$ reduced the moisture content only slightly. However, by heating the salt to $275{ }^{\circ} \mathrm{C}$ under vacuum, the water content was reduced to not more than 0.05 percent.
The $\mathrm{NH}_{4} \mathrm{ClO}_{4}$ was prepared by passing gaseous ammonia into a 70-percent aqueous solution of perchloric acid; the resulting crystals were recrystallized twice from water and then dried to constant weight at $95^{\circ} \mathrm{C}$. The ammonia was obtained from the Matheson Company, who certified it to have a purity of not less than 99.99 percent. The perchloric acid was reagent-grade material which conformed with A.C.S. specifications.

The $\mathrm{NaClO}_{4}$ was prepared by the addition of solid reagent-grade sodium hydroxide to a 70-percent aqueous solution of perchloric acid. It was recrystallized twice from water, and dried first in air at $160{ }^{\circ} \mathrm{C}$ and then in a vacuum at $275^{\circ} \mathrm{C}$.

Each of the dried perchlorates was tested for chloride by addition of a sample to a solution of silver nitrate in nitric acid; in no case was there any clouding of the solution.

\section{Units of Energy, Molecular Weights, and Conversion Factors}

The joule was used as the unit of energy. All instruments were calibrated in terms of standards maintained at NBS. For conversion to the conventional thermochemical calorie, one calorie is taken as 4.1840 joules.

All atomic weights were taken from the 1957 International Table of Atomic Weights [1]. ${ }^{1}$ The heat capacities were taken, where possible, from the literature [2]. For $\mathrm{LiClO}_{4}$, an estimated value of $24.4 \mathrm{cal} / \mathrm{deg}$ mole was used.

\footnotetext{
${ }^{1}$ Figures in brackets indicate the literature references at the end of this paper.
} 


\section{Apparatus and Procedure}

The glass calorimeter, thermometric system, apparatus for measurement of electrical energy, and general calorimetric procedure have been described $[3,4,5]$. A saturated solution of $\mathrm{KClO}_{4}$, consisting of approximately 0.0715 mole of $\mathrm{KClO}_{4}$ in 24.45 moles of water, was weighed into the calorimetric vessel, and a mixture of 0.0670 mole of $\mathrm{KCl}$ and 0.01 mole of $\mathrm{KClO}_{4}$ was added (solution $\mathrm{I}$ ). The addition of this excess of 0.01 mole of $\mathrm{KClO}_{4}$ (to insure saturation of the solution) was made in all experiments. A sealed glass ampoule of $\mathrm{LiClO}_{4}(\mathrm{c})$ was placed in the crushing device, the calorimeter was assembled, a platinum resistance thermometer was inserted, and the calorimeter was immersed in a thermostatically controlled water-bath maintained at $25.0^{\circ} \mathrm{C}$. The calorimeter temperature was adjusted to $24{ }^{\circ} \mathrm{C}$ by electrical heating. After an initial rating period the ampoule was broken into the solution. The calorimeter stirrer, operating at $90 \mathrm{rpm}$, provided sufficient agitation to afford thermal equilibrium in $30 \mathrm{~min}$. Temperatures were observed at 1-min intervals during the reaction period and at 2 -min intervals during the initial and final rating periods.

The reaction between the potassium ions and perchlorate ions caused the solution (which was already saturated) to become supersaturated with $\mathrm{KClO}_{4}$ and resulted in precipitation of the additional amount. The only change in the solution involved the addition of $\mathrm{Li}^{+}$and a corresponding decrease in the concentration of $\mathrm{K}^{+}$. For an addition of 0.030 mole of $\mathrm{LiClO}_{4}$ the resulting solution consisted of 0.0715 mole of $\mathrm{KClO}_{4}, 0.030$ mole of $\mathrm{LiCl}, 0.037$ mole of $\mathrm{KCl}$, and 24.45 moles of water (solution II) together with 0.04 mole of solid $\mathrm{KClO}_{4}$.

The experiments with $\mathrm{NH}_{4} \mathrm{ClO}_{4}$ and with $\mathrm{NaClO}_{4}$ were performed in a similar manner, producing solutions IV and V respectively. To eliminate, so far as possible, the uncertainty in the state of the precipitated $\mathrm{KClO}_{4}$, similar experiments were run using $\mathrm{KClO}_{4}$. The heat measured should correspond to the transformation of dry crystalline $\mathrm{KClO}_{4}$ to the wet precipitated salt. The calorimeter system containing solution I was calibrated with electrical energy [4], the only change in the system being the substitution of an empty bulb for the perchlorate ampoule.

The heats of solution of $\mathrm{KCl}, \mathrm{LiCl}, \mathrm{NH}_{4} \mathrm{Cl}$, and $\mathrm{NaCl}$ were determined in the same apparatus, but with a solution differing from solution I only in the quantity of $\mathrm{KCl}$, which was reduced from 0.067 mole to 0.037 mole (solution III). The addition of the $\mathrm{KCl}$ and $\mathrm{NH}_{4} \mathrm{Cl}$ samples resulted in the absorption of considerable amounts of energy; to avoid corrections for the change in the concentration of the $\mathrm{KClO}_{4}$ with temperature, a measured quantity of electrical energy was added in each case.

A separate series of electrical-energy calibration experiments was performed, using solution III and an empty ampoule.

\section{Results and Calculations}

The results of the calibration experiments on the calorimetric system used for measurement of the heats of solution of $\mathrm{LiClO}_{4}, \mathrm{NH}_{4} \mathrm{ClO}_{4}$, and $\mathrm{NaClO}_{4}$ are given in table 1. $\Delta R c$ corresponds to the corrected temperature rise of the system [6]. The energy equivalent, $E_{s}$, of the "standard" system was obtained as the ratio of the quantity of electrical energy, $E$, to $\Delta R c$, the corresponding rise in temperature.

TABLE 1. Results of the calibration experiments with solution I

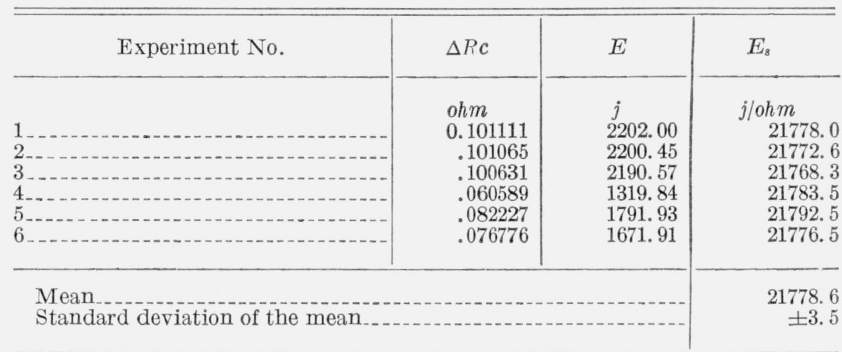

The results of the experiments on the heat of reaction of $\mathrm{LiClO}_{4}$ with $\mathrm{KCl}$ in solution $\mathrm{I}$ are given in table 2. Here, $\Delta e$ is the change in the energy equivalent from that of the "standard" system due to the heat capacity of the sample and to deviations in the mass of the glass bulbs from that of the reference bulb, $(0.444 \mathrm{~g})$. The energy evolved, $q$, was obtained as the product of $\Delta R c$ and the energy equivalent of the actual calorimetric system, $E_{s}+\Delta e$.

The results of the experiments on the heats of reaction of $\mathrm{NH}_{4} \mathrm{ClO}_{4}$ and $\mathrm{NaClO}_{4}$ with $\mathrm{KCl}$ in solution I are given in tables 3 and 4 , respectively. The results of the experiments on the heat of addition of $\mathrm{KClO}_{4}$ to solution I are given in table 5 .

The results of the calibration experiments for the system containing solution III are given in table 6. The results of the experiments on the heats of solution of $\mathrm{LiCl}, \mathrm{KCl}, \mathrm{NH}_{4} \mathrm{Cl}$, and $\mathrm{NaCl}$ in solution III are given in table $7,8,9$, and 10 , respectively.

The concentrations of the calorimetric solutions involved, on a molar basis, are as follows:

$\left[2.38 \mathrm{KClO}_{4}+2.23 \mathrm{KCl}+815 \mathrm{H}_{2} \mathrm{O}\right]$ solution $\mathrm{I}$, $\left[2.38 \mathrm{KClO}_{4}+1.23 \mathrm{KCl}+\mathrm{LiCl}+815 \mathrm{H}_{2} \mathrm{O}\right]$

$\left[2.38 \mathrm{KClO}_{4}+1.23 \mathrm{KCl}+815 \mathrm{H}_{2} \mathrm{O}\right]$ solution II

$\left[2.38 \mathrm{KClO}_{4}+1.23 \mathrm{KCl}+\mathrm{NH}_{4} \mathrm{Cl}+815 \mathrm{H}_{2} \mathrm{O}\right]$ solution IV,

$\left[2.38 \mathrm{KClO}_{4}+1.23 \mathrm{KCl}+\mathrm{NaCl}+815 \mathrm{H}_{2} \mathrm{O}\right]$ solution $\mathrm{V}$.

The calorimetric processes and the corresponding changes in enthalpy are:

$\mathrm{LiClO}_{4}(\mathrm{c})+[\mathrm{I}]=[\mathrm{II}]+\mathrm{KClO}_{4}($ pptd $)$,

$\Delta \mathrm{H}\left(25^{\circ} \mathrm{C}\right)=-62.839 \pm 0.216 \mathrm{kj} / \mathrm{mole}$,

$\mathrm{NH}_{4} \mathrm{ClO}_{4}(\mathrm{c})+[\mathrm{I}]=[\mathrm{IV}]+\mathrm{KClO}_{4}(\mathrm{pptd})$,

$\Delta \mathrm{H}\left(25^{\circ} \mathrm{C}\right)=-0.252 \pm 0.144 \mathrm{kj} / \mathrm{mole}$, 
TABLE 2. Heat reaction of $\mathrm{LiClO}_{4}$ with $\mathrm{KCl}$ in solution I

\begin{tabular}{|c|c|c|c|c|c|}
\hline Experiment No. & $\Delta R c$ & $\Delta e$ & $q$ & $\mathrm{LiClO}_{4}$ & $-\Delta \mathrm{H}\left(25^{\circ} \mathrm{C}\right)$ \\
\hline $\begin{array}{l}1 \\
2 \\
3 \\
4 \\
4\end{array}$ & $\begin{array}{l}\text { ohm } \\
0.074983 \\
.074319 \\
.082012 \\
.078088 \\
.072577\end{array}$ & $\begin{array}{l}\text { j/ohm } \\
27.1 \\
29.3 \\
29.8 \\
27.6 \\
27.0\end{array}$ & $\begin{array}{c}j \\
1635.1 \\
1620.7 \\
1788.6 \\
1702.8 \\
1582.6\end{array}$ & $\begin{array}{l}\text { mole } \\
0.026135 \\
.025660 \\
.028523 \\
.027131 \\
.025120\end{array}$ & $\begin{array}{r}\mathrm{kj} / \mathrm{mole} \\
62.564 \\
63.161 \\
62.707 \\
62.762 \\
63.002\end{array}$ \\
\hline \multicolumn{5}{|c|}{$\begin{array}{l}\text { Mean } \\
\text { Standard deviation of the mean }\end{array}$} & 62.839 \\
\hline
\end{tabular}

TABLE 3. Heat of reaction of $\mathrm{NH}_{4} \mathrm{ClO}_{4}$ with $\mathrm{KCl}$ in solution $I$

\begin{tabular}{|c|c|c|c|c|c|}
\hline Experiment No. & $\Delta R c$ & $\Delta e$ & $q$ & $\mathrm{NH}_{4} \mathrm{ClO}_{4}$ & $-\Delta \mathrm{H}\left(25^{\circ} \mathrm{C}\right)$ \\
\hline & $\begin{array}{l}\text { ohm } \\
0.000472\end{array}$ & $\begin{array}{l}j / 0 h m \\
\quad 43.8\end{array}$ & $\stackrel{j}{10.30}$ & $\begin{array}{l}\text { mole } \\
0.024314\end{array}$ & $\begin{array}{l}\mathrm{kj} / \mathrm{mole} \\
0.424\end{array}$ \\
\hline & .000250 & 38. 4 & 5. 45 & .021541 & .253 \\
\hline $\begin{array}{l}3 \\
4 \\
4 \ldots \ldots . . . . \\
\end{array}$ & $\begin{array}{l}.0000505 \\
.00430\end{array}$ & $\begin{array}{l}29.0 \\
41.4\end{array}$ & 9.38 & $\begin{array}{l}.023137 \\
.023137\end{array}$ & \\
\hline $5 \ldots$ & .000034 & 47.9 & 0.74 & .026663 & .028 \\
\hline $6 \ldots$ & .000066 & 54.4 & 1.45 & .030132 & .048 \\
\hline
\end{tabular}

Mean

Standard deviation of the mean.

0.252

TABLE 4. Heat of solution of $\mathrm{NaClO}_{4}$ with $\mathrm{KCl}$ in solution I

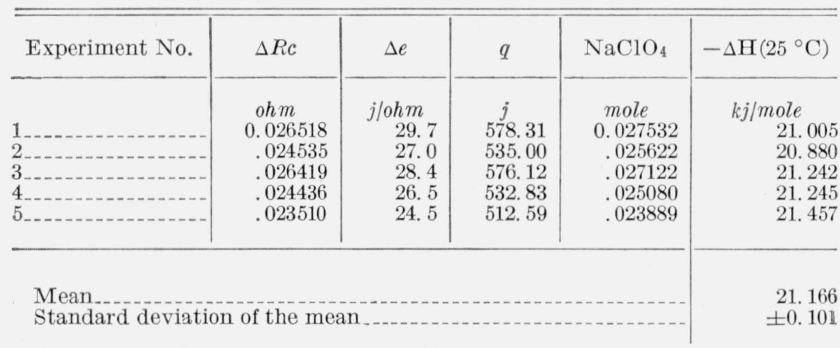

TABLE 5. Heat of addition of $\mathrm{KClO}_{4}$ to solution I

\begin{tabular}{|c|c|c|c|c|c|}
\hline Experiment No. & $\Delta R c$ & $\Delta e$ & $q$ & $\mathrm{KClO}_{4}$ & $-\Delta \mathrm{H}\left(25^{\circ} \mathrm{C}\right)$ \\
\hline $\begin{array}{l}1 \\
2 \\
3 \\
4 \\
5\end{array}$ & $\begin{array}{l}\text { ohm } \\
0.000108 \\
.000071 \\
.000034 \\
.000107 \\
.000006\end{array}$ & $\begin{array}{l}j / 0 h m \\
21.8 \\
24.7 \\
25.3 \\
27.9 \\
25.4\end{array}$ & $\begin{array}{l}j \\
2.35 \\
1.55 \\
0.74 \\
2.33 \\
0.13\end{array}$ & $\begin{array}{l}\text { mole } \\
0.01991 \\
.02225 \\
.02287 \\
.02424 \\
.02240\end{array}$ & $\begin{array}{r}\mathrm{kj} / \text { mole } \\
0.118 \\
.070 \\
.032 \\
.096 \\
.058\end{array}$ \\
\hline \multicolumn{5}{|c|}{$\begin{array}{l}\text { Mean } \\
\text { Standard deviation of the mean }\end{array}$} & $\begin{array}{r}0.075 \\
\pm 0.015\end{array}$ \\
\hline
\end{tabular}

TABLE 6. Results of the calibration experiments with solution III

\begin{tabular}{|c|c|c|c|}
\hline Experiment No. & $\Delta R c$ & $E$ & $E_{s}$ \\
\hline $\begin{array}{l}12- \\
2 \\
3- \\
4- \\
6 \\
6\end{array}$ & $\begin{array}{l}\text { ohm } \\
0.100665 \\
.101224 \\
.100624 \\
.085369 \\
.099602 \\
.099575\end{array}$ & $\begin{array}{l}j \\
2203.51 \\
2215.17 \\
2200.52 \\
1869.01 \\
2179.06 \\
2177.48\end{array}$ & $\begin{array}{l}\text { j/ohm } \\
21889.5 \\
21883.8 \\
21868.7 \\
21893.3 \\
21877.7 \\
21867.7\end{array}$ \\
\hline \multicolumn{3}{|c|}{$\begin{array}{l}\text { Mean } \\
\text { Standard deviation of the mean }\end{array}$} & $\begin{array}{r}21880.1 \\
\quad \pm 4.3\end{array}$ \\
\hline
\end{tabular}

TABLE 7. Heat of solution of $\mathrm{LiCl}$ in solution III

\begin{tabular}{|c|c|c|c|c|c|}
\hline Experiment No. & $\Delta R c$ & $\Delta e$ & $q$ & $\mathrm{LiCl}$ & $-\Delta \mathrm{H}\left(25^{\circ} \mathrm{C}\right)$ \\
\hline $\begin{array}{l}1 \\
2 \ldots \ldots \\
3 \\
4 \\
5 \\
5\end{array}$ & $\begin{array}{c}\text { ohm } \\
0.059686 \\
.057614 \\
.085069 \\
.071628 \\
.078054\end{array}$ & $\begin{array}{l}\text { j/ohm } \\
17.8 \\
17.6 \\
26.6 \\
22.6 \\
24.9\end{array}$ & $\begin{array}{c}j \\
1307.0 \\
1261.6 \\
1863.6 \\
1568.8 \\
1709.8\end{array}$ & $\begin{array}{c}\text { mole } \\
0.0378442 \\
.0368166 \\
.0539895 \\
.0456099 \\
.0496536\end{array}$ & $\begin{array}{l}k j / m o l e \\
\text { 34. } 536 \\
\text { 34. } 267 \\
34.518 \\
34.397 \\
34.435\end{array}$ \\
\hline \multicolumn{5}{|c|}{$\begin{array}{l}\text { Mean } \\
\text { Standard deviation of the mean }\end{array}$} & $\begin{array}{r}34.431 \\
\pm 0.048\end{array}$ \\
\hline
\end{tabular}

TABLE 8. Heat of solution of $\mathrm{KCl}$ in solution III

\begin{tabular}{|c|c|c|c|c|c|c|}
\hline $\begin{array}{l}\text { Experiment } \\
\text { No. }\end{array}$ & $\Delta R c$ & $\Delta e$ & $E$ & $q$ & $\mathrm{KCl}$ & $-\Delta \mathrm{H}\left(25^{\circ} \mathrm{C}\right)$ \\
\hline $\begin{array}{l}1 \\
2 \\
3 \\
4 \\
5 \\
6\end{array}$ & $\begin{array}{c}\text { ohm } \\
0.099847 \\
.099712 \\
.098928 \\
.100757 \\
.099508 \\
.099260\end{array}$ & $\begin{array}{r}j / \text { ohm } \\
14.4 \\
13.7 \\
14.0 \\
15.8 \\
15.1 \\
14.5\end{array}$ & $\begin{array}{c}j \\
2293.8 \\
2282.6 \\
2279.7 \\
2324.1 \\
2297.4 \\
2292.9\end{array}$ & $\begin{aligned} & j \\
&-107.7 \\
&-99.5 \\
&-113.8 \\
&-117.9 \\
&-118.7 \\
&-119.6\end{aligned}$ & $\begin{array}{c}\text { mole } \\
0.029285 \\
.026790 \\
.028950 \\
.031030 \\
.029810 \\
.029946\end{array}$ & $\begin{aligned} & k j / \text { mole } \\
&-3.678 \\
&-3.714 \\
&-3.931 \\
&-3.800 \\
&-3.982 \\
&-3.994\end{aligned}$ \\
\hline \multicolumn{6}{|c|}{$\begin{array}{l}\text { Mean } \\
\text { Standard deviation of the mean }\end{array}$} & $\begin{array}{l}-3.850 \\
\pm 0.056\end{array}$ \\
\hline
\end{tabular}

TABLE 9. Heat of solution of $\mathrm{NH}_{4} \mathrm{Cl}$ in solution III

\begin{tabular}{|c|c|c|c|c|c|c|}
\hline $\begin{array}{c}\text { Experiment } \\
\text { No. }\end{array}$ & $\Delta R c$ & $\Delta e$ & $E$ & $q$ & $\mathrm{NH}_{4} \mathrm{Cl}$ & $-\Delta \mathrm{H}\left(25^{\circ} \mathrm{C}\right)$ \\
\hline $\begin{array}{l}1 \\
2 \\
3 \\
4\end{array}$ & $\begin{array}{c}\text { ohm } \\
0.089184 \\
.085337 \\
.090007 \\
.085593 \\
.089177\end{array}$ & $\begin{array}{r}j / \mathrm{ohm} \\
31.1 \\
31.0 \\
29.0 \\
28.1 \\
34.3\end{array}$ & $\begin{array}{c}j \\
2673.1 \\
2567.2 \\
2629.4 \\
2527.3 \\
2720.9\end{array}$ & $\begin{array}{c}j \\
-719.0 \\
-697.4 \\
-657.4 \\
-652.1 \\
-766.6\end{array}$ & $\begin{array}{c}\text { mole } \\
0.037639 \\
.036725 \\
.034397 \\
.034031 \\
.040300\end{array}$ & $\begin{array}{l}k j / \text { mole } \\
\quad-19.103 \\
\quad-18.990 \\
-19.112 \\
-19.162 \\
-19.022\end{array}$ \\
\hline \multicolumn{6}{|c|}{$\begin{array}{l}\text { Mean } \\
\text { Standard deviation of the mean }\end{array}$} & $\begin{array}{r}-19.078 \\
\pm 0.031\end{array}$ \\
\hline
\end{tabular}

TABLE 10. Heat of solution of $\mathrm{NaCl}$ in solution III

\begin{tabular}{|c|c|c|c|c|c|}
\hline $\begin{array}{l}\text { Experiment } \\
\text { No. }\end{array}$ & $\Delta R c$ & $\Delta e$ & $q$ & $\mathrm{NaCl}$ & $-\Delta \mathrm{H}\left(25^{\circ} \mathrm{C}\right)$ \\
\hline $\begin{array}{l}1 \\
2 \\
3 \\
4 \\
5 \\
6\end{array}$ & $\begin{array}{l}\text { ohm } \\
-0.009690 \\
-.009086 \\
-.009335 \\
-.009489 \\
-.009642 \\
-.009153\end{array}$ & $\begin{array}{r}\text { j/ohm } \\
15.6 \\
13.8 \\
15.9 \\
14.9 \\
14.6 \\
14.7\end{array}$ & $\begin{array}{c}j \\
-212.17 \\
-198.93 \\
-204.40 \\
-207.76 \\
-211.11 \\
-200.40\end{array}$ & $\begin{array}{c}\text { mole } \\
0.029920 \\
.028985 \\
.029964 \\
.028691 \\
.029950 \\
.028847\end{array}$ & $\begin{aligned} & k j / m o l e \\
&-7.091 \\
&-6.863 \\
&-6.822 \\
&-7.241 \\
&-7.049 \\
&-6.947\end{aligned}$ \\
\hline \multicolumn{5}{|c|}{$\begin{array}{l}\text { Mean } \\
\text { Standard deviation of the mean }\end{array}$} & $\begin{array}{l}-7.002 \\
\pm 0.064\end{array}$ \\
\hline
\end{tabular}

$\mathrm{NaClO}_{4}(\mathrm{c})+[\mathrm{I}]=[\mathrm{V}]+\mathrm{KClO}_{4}(\mathrm{pptd})$,

$\Delta \mathrm{H}\left(25^{\circ} \mathrm{C}\right)=-21.166 \pm 0.202 \mathrm{kj} / \mathrm{mole}$,

$\mathrm{KCl}(\mathrm{c})+[\mathrm{III}]=[\mathrm{I}]$,

$\Delta \mathrm{H}\left(25^{\circ} \mathrm{C}\right)=3.850 \pm 0.112 \mathrm{kj} / \mathrm{mole}$,

$\mathrm{LiCl}(\mathrm{c})+[\mathrm{III}]=[\mathrm{II}]$

$\Delta \mathrm{H}\left(25^{\circ} \mathrm{C}\right)=-34.431 \pm 0.096 \mathrm{kj} / \mathrm{mole}$,

$\mathrm{NH}_{4} \mathrm{Cl}(\mathrm{c})+[\mathrm{III}]=[\mathrm{IV}]$,

$\Delta \mathrm{H}\left(25^{\circ} \mathrm{C}\right)=19.078 \pm 0.062 \mathrm{kj} / \mathrm{mole}$,

$\mathrm{NaCl}(\mathrm{c})+[\mathrm{III}]=[\mathrm{V}]$,

$\Delta \mathrm{H}\left(25^{\circ} \mathrm{C}\right)=7.002 \pm 0.128 \mathrm{kj} / \mathrm{mole}$, 
$\mathrm{KClO}_{4}(\mathrm{c})+[\mathrm{I}]=[\mathrm{I}]+\mathrm{KClO}_{4}(\mathrm{pptd})$,

$\Delta \mathrm{H}\left(25^{\circ} \mathrm{C}\right)=-0.075 \pm 0.030 \mathrm{kj} / \mathrm{mole}$.

The appropriate combinations of the above equations yield the following processes:

$\mathrm{LiClO}_{4}(\mathrm{c})+\mathrm{KCl}(\mathrm{c})=\mathrm{LiCl}(\mathrm{c})+\mathrm{KClO}_{4}(\mathrm{c})$, $\Delta \mathrm{H}^{\circ}\left(25^{\circ} \mathrm{C}\right)=-24.483 \pm 0.260 \mathrm{kj} / \mathrm{mole}$, $=-5.855 \pm 0.062 \mathrm{kcal} / \mathrm{mole}$,

$\mathrm{NH}_{4} \mathrm{ClO}_{4}(\mathrm{c})+\mathrm{KCl}(\mathrm{c})=\mathrm{NH}_{4} \mathrm{Cl}(\mathrm{c})+\mathrm{KClO}_{4}(\mathrm{c})$, $\Delta \mathrm{H}^{\circ}\left(25^{\circ} \mathrm{C}\right)=-15.405 \pm 0.195 \mathrm{kj} / \mathrm{mole}$, $=-3.682 \pm 0.047 \mathrm{kcal} / \mathrm{mole}$,

$\mathrm{NaClO}_{4}(\mathrm{c})+\mathrm{KCl}(\mathrm{c})=\mathrm{NaCl}(\mathrm{c})+\mathrm{KClO}_{4}(\mathrm{c})$, $\Delta \mathrm{H}^{\circ}\left(25^{\circ} \mathrm{C}\right)=-24.243 \pm 0.266 \mathrm{kj} / \mathrm{mole}$, $=-5.794 \pm 0.064 \mathrm{kcal} / \mathrm{mole}$.

We have combined the results given in eqs 9,10 , and 11 with our value of $-4.02 \pm 0.40 \mathrm{kj} / \mathrm{mole}$ for the heat of decomposition of potassium perchlorate, reported in the preceding paper [7], and with values for the heats of formation of $\mathrm{KCl}(\mathrm{c}), \mathrm{LiCl}(\mathrm{c})$, $\mathrm{NH}_{4} \mathrm{Cl}(\mathrm{c})$, and $\mathrm{NaCl}(\mathrm{c})$ [2], and have obtained the following heats of formation:

$\mathrm{LiClO}_{4}(\mathrm{c}), \quad \Delta \mathrm{Hf}^{\circ}\left(25^{\circ} \mathrm{C}\right)=-380.27 \pm 1.21 \mathrm{kj} / \mathrm{mole}$ $=-90.89 \pm 0.29 \mathrm{kcal} / \mathrm{mole}$,

$\mathrm{NH}_{4} \mathrm{ClO}_{4}(\mathrm{c}), \Delta \mathrm{Hf}^{\circ}\left(25^{\circ} \mathrm{C}\right)=-295.98 \pm 1.35 \mathrm{kj} / \mathrm{mole}$ $=-70.74 \pm 0.32 \mathrm{kcal} / \mathrm{mole}$,

$\mathrm{NaClO}_{4}(\mathrm{c}), \quad \Delta \mathrm{Hf}^{\circ}\left(25^{\circ} \mathrm{C}\right)=-382.75 \pm 0.93 \mathrm{kj} / \mathrm{mole}$ $=-91.48 \pm 0.22 \mathrm{kcal} / \mathrm{mole}$.

\section{Discussion}

Rossini, Wagman, Evans, Levine, and Jaffe [2] have selected -69.42 and $-92.18 \mathrm{kcal} / \mathrm{mole}$, respectively, for the standard heats of formation of $\mathrm{NH}_{4} \mathrm{ClO}_{4}(\mathrm{c})$ and $\mathrm{NaClO}_{4}(\mathrm{c})$, based upon the data prior to 1950. However, since these values were based on $-103.6 \mathrm{kcal} /$ mole for the heat of formation of $\mathrm{KClO}_{4}$, we have made a correction of $0.38 \mathrm{kcal} /$ mole and have obtained -69.04 and $-91.80 \mathrm{kcal} /$ mole, respectively, for $\mathrm{NH}_{4} \mathrm{ClO}_{4}(\mathrm{c})$ and $\mathrm{NaClO}_{4}(\mathrm{c})$.

Markowitz, Harris, and Stewart [8] measured the heats of reaction between aqueous solutions of $\mathrm{LiOH}$ and $\mathrm{HClO}_{4}$, and the heat of solution, in water, of anhydrous $\mathrm{LiClO}_{4}$. They obtained $-91.70 \mathrm{kcal} /$ mole for the heat of formation of $\mathrm{LiClO}_{4}$ based on the heats of formation of $\mathrm{LiOH}(\mathrm{aq})$ and $\mathrm{HClO}_{4}(\mathrm{aq})$ [2]. However, since the heat of formation of $\mathrm{HClO}_{4}(\mathrm{aq})$ was based on $-103.6 \mathrm{kcal} / \mathrm{mole}$ for the heat of formation of $\mathrm{KClO}_{4}$ [2], we have made a correction of $0.38 \mathrm{kcal}$ to their data, obtaining $-91.32 \mathrm{kcal} / \mathrm{mole}$ for the heat of formation of $\mathrm{LiClO}_{4}(\mathrm{c})$.

Birky and Hepler [9] measured the heats of solution in water, of $\mathrm{KClO}_{4}(\mathrm{c}), \mathrm{NH}_{4} \mathrm{ClO}_{4}(\mathrm{c})$, and $\mathrm{LiClO}_{4}(\mathrm{c})$, and obtained -70.63 and $-91.11 \mathrm{kcal} /$ mole, respectively, for the heats of formation of $\mathrm{NH}_{4} \mathrm{ClO}_{4}(\mathrm{c})$ and $\mathrm{LiClO}_{4}(\mathrm{c})$. Their data are based on the heat of formation of $\mathrm{KClO}_{4}(\mathrm{c})$ [7] and on the heats of formation of $\mathrm{K}^{+}(\mathrm{aq}), \mathrm{Li}^{+}(\mathrm{aq})$, and $\mathrm{NH}_{4}^{+}(\mathrm{aq})$ [2]

The heats of formation in kcal/mole at $25{ }^{\circ} \mathrm{C}$ obtained by the various investigators are compared with the results of the present investigation in the following tabulation:

\begin{tabular}{|c|c|c|c|}
\hline & $\mathrm{LiClO}_{4}$ & $\mathrm{NH}_{4} \mathrm{ClO}_{4}$ & $\mathrm{NaClO}_{4}$ \\
\hline $\begin{array}{l}\text { Rossini, Wagman, Evans, et al. } \\
\text { [2]. }\end{array}$ & & -69.04 & -91.80 \\
\hline $\begin{array}{l}\text { Markowitz, Harris, and Stewart } \\
\text { [8]. }\end{array}$ & -91.32 & & \\
\hline $\begin{array}{l}\text { Birky and Hepler [9] } \\
\text { This investigation }\end{array}$ & $\begin{array}{r}-91.11 \\
-90.89 \pm 0.29\end{array}$ & $\begin{array}{r}-70.63 \\
-70.74 \pm 0.32\end{array}$ & $-91.48 \pm 0.22$ \\
\hline
\end{tabular}

\section{References}

[1] E. Wichers, J. Am. Chem. Soc. 80, 4121 (1958).

[2] F. D. Rossini, D. D. Wagman, W. H. Evans, S. Levine, and I. Jaffe, Selected values of chemical thermodynamic properties, NBS Circ. 500 (U.S. Government Printing Office, Washington 25, D.C., 1952)

[3] W. H. Johnson, A. A. Gilliland, and E. J. Prosen, J. Research NBS 63A, 161 (1959).

[4] E. J. Prosen, W. H. Johnson, and F. Y. Pergiel, J. Research NBS 62, 43 (1959) RP2927.

[5] E. J. Prosen, F. W. Maron, and F. D. Rossini, J. Research NBS 46, 106 (1951) RP2181.

[6] E. J. Prosen, Chapter 6 in Experimental thermochemistry, F. D. Rossini, ed. (Interscience Publishers, Inc., New York, N.Y., 1956).

[7] W. H. Johnson and A. A. Gilliland, J. Research NBS 65A (1961).

[8] M. Markowitz, R. F. Harris, and H. Stewart, Jr., J. Phys. Chem. 63, 1325 (1959).

[9] M. M. Birky and L. G. Hepler, J. Phys. Chem. 64, 686 (1960).

(Paper 65A1-85) 